Review

\title{
Structure of Buried Ice on Mars
}

\author{
${ }^{1}$ Relly Victoria Petrescu, ${ }^{2}$ Raffaella Aversa, \\ ${ }^{2}$ Antonio Apicella and ${ }^{1}$ Florian Ion Tiberiu Petrescu \\ ${ }^{I}$ ARoTMM-IFToMM, Bucharest Polytechnic University, Bucharest, (CE), Romania \\ ${ }^{2}$ Department of Architecture and Industrial Design, Advanced Material Lab, \\ Second University of Naples, 81031 Aversa (CE), Italy
}

Article history

Received: 14-01-2018

Revised: 16-01-2018

Accepted: 22-01-2018

Corresponding Author: Florian Ion Tiberiu Petrescu ARoTMM-IFToMM,

Bucharest Polytechnic

University, Bucharest, (CE),

Romania

E-mail: scipub02@gmail.com
Abstract: After the older evidence that there is carbon dioxide on Mars made up of oxygen 2 and carbon now we have evidence that there is even normal water on the marble consisting of hydrogen 2 and oxygen. In other words, we have Martian oxygen combined with carbon and hydrogen, so we can extract oxygen directly to the site to initially create the source of the breathing necessary for those who will originally live in closed bases built on Mars in the form of huge bells, extremely solid, which will be permanently fed with oxygen for human respiration, but also for other beings, including pets. Our main objective, however, is to create the atmosphere on Mars, a ground-like, welcoming, friendly atmosphere, so that in the end Mars can live in the same way as on Earth. It is no longer a dream, but an imperative requirement. It is still difficult to conquer the very distant exoplanets we have just discovered and paratroop and yet we will do so slowly over time and then, as much as possible, it is imperative to begin the terratation of our Mars neighbor, showing clear signs that it was habitable or perhaps once inhabited and which today reveals real water, apart from the carbon dioxide that has been discovered for many years in following. Hydrogen being the number one element can now be obtained almost anywhere through various nuclear reactions. If we have oxygen extracted from the layers of $\mathrm{CO}_{2}$ or the water we have found recently, we can create a source of breath and then we can produce water in massive quantities, with the obvious purpose of rebuilding the friendly atmosphere of Mars to create a natural water circuit on Mars, even if originally it will be artificially produced using modern technologies. The most difficult problem was to find a source of oxygen on Mars, so we would not be forced to produce the necessary oxygen in massive amounts to terrify the planet from other substances through nuclear reactions. If there are already serious sources of carbon snow, plus the recently discovered sources of pure water, we can obviously extract the oxygen directly from them. How we have shown hydrogen production will not be a difficult issue, being element 1 so easy to obtain even from any other element through nuclear reactions first. If our solar system and our universe abound in hydrogen sources, there are still no obvious abundant sources of pure, elemental hydrogen on Mars. Frankly, even on our planet Terra, hydrogen even today does not abound as a pure element, being extracted or produced from water, hydrocarbons, or other elements through nuclear reactions. To create water on Mars, we already have clear possibilities due to the existence of oxygen and the possibility of extraction and hydrogen extraction. For a normal atmosphere and on Mars it is also necessary, besides oxygen and hydrogen, the nitrogen element. Here studies must be concentrated to find in the coming years and sources of nitrogen directly on the planet today, which we want to turn into a second blue planet in our solar system soon.

Keywords: NASA, Mars, Atmosphere, Stratosphere, Water, Oxygen, Hydrogen, Nitrogen 


\section{Introduction}

Researchers using NASA's Mars Reconnaissance Orbiter (MRO) have found eight sites where thick deposits of ice beneath Mars' surface are exposed in faces of eroding slopes (Fig. 1 and 2).

These eight scarps, with slopes as steep as $55^{\circ} \mathrm{C}$, reveal new information about the internal layered structure of previously detected underground ice sheets in Mars' middle latitudes.

The ice was likely deposited as snow long ago. The deposits are exposed in cross section as relatively pure water ice, capped by a layer one to two yards (or meters) thick of ice-cemented rock and dust. They hold clues about Mars' climate history. They also may make frozen water more accessible than previously thought to future robotic or human exploration missions.

Researchers who located and studied the scarp sites with the High-Resolution Imaging Science Experiment (HiRISE) camera on MRO reported the findings today in the journal Science. The sites are in both northern and southern hemispheres of Mars, at latitudes from about 55 to $58^{\circ} \mathrm{C}$, equivalent on Earth to Scotland or the tip of South America.

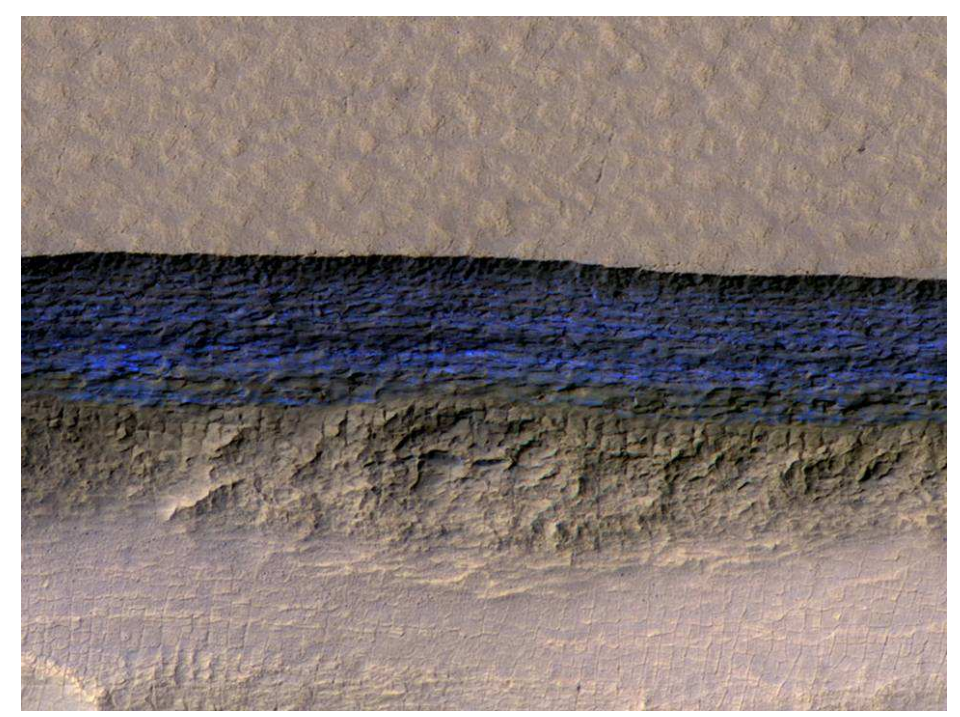

Fig. 1: A cross-section of underground ice is exposed at the steep slope that appears bright blue in this enhanced-color view from the HiRISE camera on NASA's Mars Reconnaissance Orbiter. The scene is about 550 yards wide. The scarp drops about 140 yards from the level ground in the upper third of the image. Image Credit: NASA/JPL-Caltech/UA/USGS

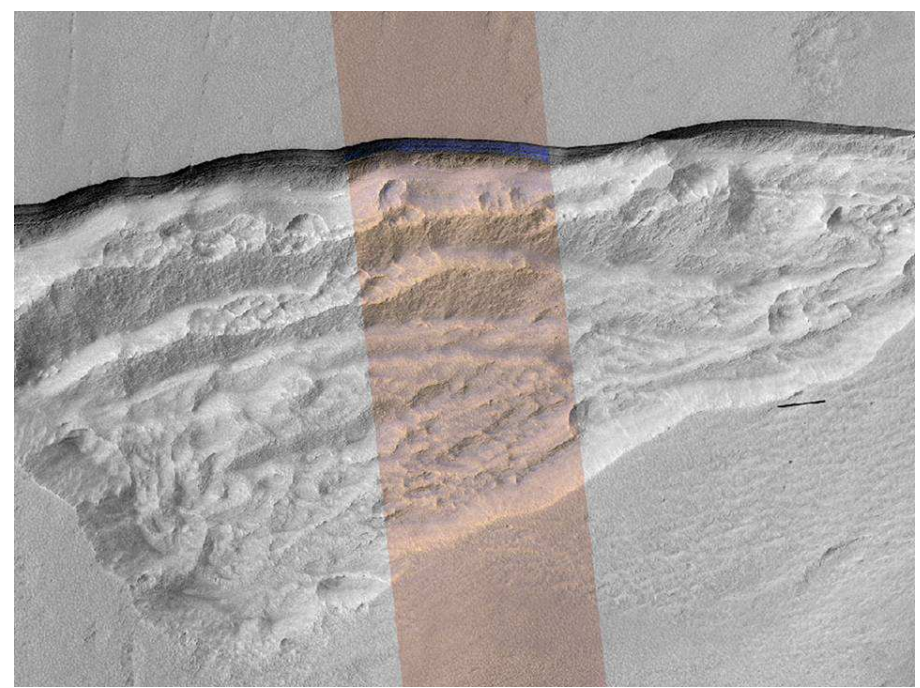

Fig. 2: At this pit on Mars, the steep slope at the northern edge (toward the top of the image) exposes a cross-section of a thick sheet of underground water ice. The image is from the HiRISE camera on NASA's Mars Reconnaissance Orbiter, with an enhanced-color central swath between grayscale on each side. Image Credit: NASA/JPL-Caltech/UA/USGS 
"There is shallow ground ice under roughly a third of the Martian surface, which records the recent history of Mars," said the study's lead author, Colin Dundas of the U.S. Geological Survey's Astrogeology Science Center in Flagstaff, Arizona. "What we've seen here are crosssections through the ice that give us a 3-D view with more detail than ever before."

The scarps directly expose bright glimpses into vast underground ice previously detected with spectrometers on NASA's Mars Odyssey orbiter, with groundpenetrating radar instruments on MRO and on the European Space Agency's Mars Express orbiter and with observations of fresh impact craters that uncover subsurface ice. NASA sent the Phoenix lander to Mars in response to the Odyssey findings; in 2008, the Phoenix mission confirmed and analyzed the buried water ice at $68^{\circ} \mathrm{C}$ north latitude, about one-third of the way to the pole from the northernmost of the eight scarp sites.

The discovery reported today gives us surprising windows where we can see right into these thick underground sheets of ice," said Shane Byrne of the University of Arizona Lunar and Planetary Laboratory, Tucson, a co-author on today's report. "It's like having one of those ant farms where you can see through the glass on the side to learn about what's usually hidden beneath the ground."

Scientists have not determined how these particular scarps initially form. However, once the buried ice becomes exposed to Mars' atmosphere, a scarp likely grows wider and taller as it "retreats," due to sublimation of the ice directly from solid form into water vapor. At some of them, the exposed deposit of water ice is more than 100 yards, or meter, thick. Examination of some of the scarps with MRO's Compact Reconnaissance Imaging Spectrometer for Mars (CRISM) confirmed that the bright material is frozen water. A check of the surface temperature using Odyssey's Thermal Emission Imaging System (THEMIS) camera helped researchers determine they're not seeing just thin frost covering the ground.

Researchers previously used MRO's Shallow Radar (SHARAD) to map extensive underground water-ice sheets in middle latitudes of Mars and estimate that the top of the ice is less than about 10 yards beneath the ground surface. How much less? The radar method did not have sufficient resolution to say. The new ice-scarp studies confirm indications from fresh-crater and neutron-spectrometer observations that a layer rich in water ice begins within just one or two yards of the surface in some areas.

The new study not only suggests that underground water ice lies under a thin covering over wide areas, it also identifies eight sites where ice is directly accessible, at latitudes with less hostile conditions than at Mars' polar ice caps. "Astronauts could essentially just go there with a bucket and a shovel and get all the water they need," Byrne said.

The exposed ice has scientific value apart from its potential resource value because it preserves evidence about long-term patterns in Mars' climate. The tilt of Mars' axis of rotation varies much more than Earth's, over rhythms of millions of years. Today the two planets' tilts are about the same. When Mars tilts more, climate conditions may favor the buildup of middle-latitude ice. Dundas and co-authors say that banding and color variations apparent in some of the scarps suggest layers "possibly deposited with changes in the proportion of ice and dust under varying climate conditions."

This research benefited from the coordinated use of multiple instruments on Mars orbiters, plus the longevities at Mars now exceeding 11 years for MRO and 16 years for Odyssey. Orbital observations will continue, but future missions to the surface could seek additional information.

"If you had a mission at one of these sites, sampling the layers going down the scarp, you could get a detailed climate history of Mars," suggested MRO Deputy Project Scientist Leslie Tamppari of NASA's Jet Propulsion Laboratory, Pasadena, California. "It's part of the whole story of what happens to water on Mars over time: Where does it go? When does ice accumulate? When does it recede?"

The University of Arizona operates HiRISE, which was built by Ball Aerospace and Technologies Corp., Boulder, Colorado. The Johns Hopkins University Applied Physics Laboratory, Laurel, Maryland, leads MRO's CRISM investigation. The Italian Space Agency provided MRO's SHARAD instrument, Sapienza University of Rome leads SHARAD operations and the Planetary Science Institute, based in Tucson, Arizona, leads U.S. involvement in SHARAD. Arizona State University, Tempe, leads the Odyssey mission's THEMIS investigation. JPL, a division of Caltech in Pasadena, California, manages the MRO and Odyssey projects for the NASA Science Mission Directorate in Washington. Lockheed Martin Space, Denver, built both orbiters and supports their operation (Webster et al., 2018; Aversa et al., 2017a; 2017b; 2017c; 2017d; 2017e; 2017f; 2016a; 2016b; 2016c; 2016d; 2016e; 2016f; 2016g; 2016h; 2016i; 2016j; 2016k; 2016l; 2016m; 2016n; 2016o; Berto et al., 2016a; 2016b; 2016c; 2016d; Mirsayar et al., 2017; Petrescu and Petrescu, 2016a; 2016b; 2016c; 2013a; 2013b; 2013c; 2013d; 2012a; 2012b; 2012c; 2012d; 2011a; 2011b; Petrescu, 2016; 2012a; 2012b; 2009; Petrescu and Calautit, 2016a; 2016b; Petrescu et al., 2016a; 2016b; 2016c; Petrescu et al., 2017a; 2017b; 2017c; 2017d; 2017e; 2017f; 2017g; 2017h; 2017i; 2017j; 2017k; 2017l).

\section{Materials and Methods}

It was the spring of the northern hemisphere, when this photo was taken on May 21, 2017, at local time Mars at 13:21 by HiRISE on Mars Reconnaissance Orbiter at NASA. In winter, the snow and ice covered the dunes inexorably. Unlike Earth, this snow and ice are carbon dioxide, better known as dry ice (Fig. 3). 


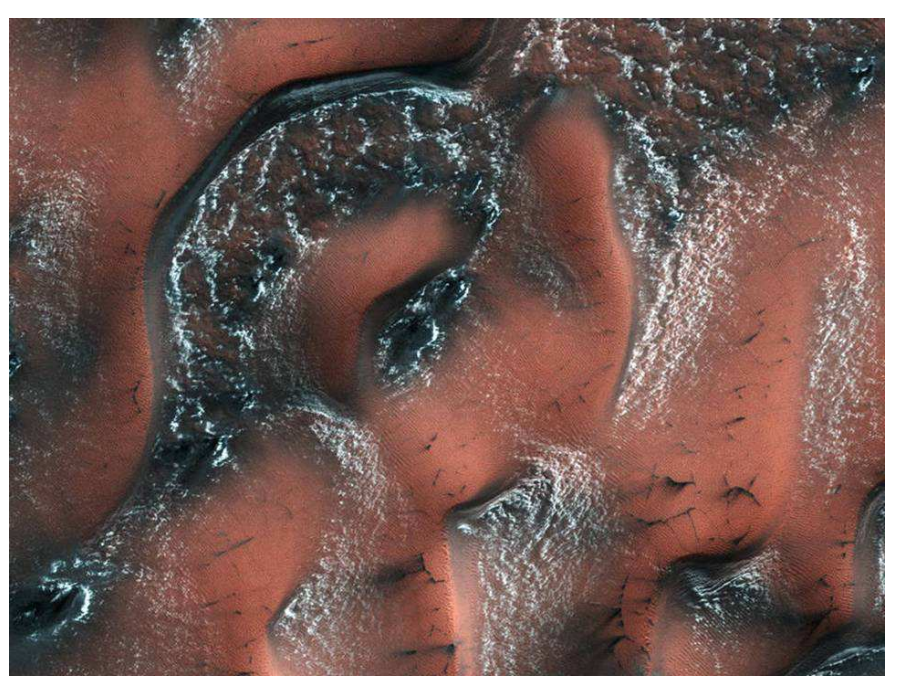

Fig. 3: Over the winter, snow and ice have inexorably covered the dunes. Unlike on Earth, this snow and ice is carbon dioxide, better known to us as dry ice

When the sun starts to shine on it in the spring, the ice on the smooth surface of the dune breaks and the drainage gas gives the black sand of the dune under water, often creating beautiful patterns. On the hard surface of the dunes, frost is captured behind the adjacent small edges.

NASA's Jet Propulsion Laboratory, a division of the California Institute of Technology in Pasadena, California, heads Mars Reconnaissance Orbiter for the NASA Department of Science, Washington. The HiRISE camera was built by Ball Aerospace and Technology Corporation and operated by the University of Arizona.

\section{Results}

After the older evidence that there is carbon dioxide on Mars made up of oxygen 2 and carbon now we have evidence that there is even normal water on the marble consisting of hydrogen 2 and oxygen.

In other words, we have Martian oxygen combined with carbon and hydrogen, so we can extract oxygen directly to the site to initially create the source of the breathing necessary for those who will originally live in closed bases built on Mars in the form of huge bells, extremely solid, which will be permanently fed with oxygen for human respiration, but also for other beings, including pets.

Our main objective, however, is to create the atmosphere on Mars, a ground-like, welcoming, friendly atmosphere, so that in the end Mars can live in the same way as on Earth.

It is no longer a dream, but an imperative requirement. It is still difficult to conquer the very distant exoplanes we have just discovered and paratroop and yet we will do so slowly over time.

And then, as much as possible, it is imperative to begin the terratation of our Mars neighbor, showing clear signs that it was habitable or perhaps once inhabited and which today reveals real water, apart from the carbon dioxide that has been discovered for many years in follow.

Hydrogen being the number one element can now be obtained almost anywhere through various nuclear reactions. If we have oxygen extracted from the layers of $\mathrm{CO}_{2}$ or the water we have found recently, we can create a source of breath and then we can produce water in massive quantities, with the obvious purpose of rebuilding the friendly atmosphere of Mars to create a natural water circuit on Mars, even if originally it will be artificially produced using modern technologies.

The most difficult problem was to find a source of oxygen on Mars, so we would not be forced to produce the necessary oxygen in massive amounts to terrify the planet from other substances through nuclear reactions. If there are already serious sources of carbon snow, plus the recently discovered sources of pure water, we can obviously extract the oxygen directly from them.

How we have shown hydrogen production will not be a difficult issue, being element 1 so easy to obtain even from any other element through nuclear reactions first. If our solar system and our universe abound in hydrogen sources, there are still no obvious abundant sources of pure, elemental hydrogen on Mars.

Frankly, even on our planet Terra, hydrogen even today does not abound as a pure element, being extracted or produced from water, hydrocarbons, or other elements through nuclear reactions.

To create water on Mars, we already have clear possibilities due to the existence of oxygen and the possibility of extraction and hydrogen extraction.

For a normal atmosphere and on Mars it is also necessary, besides oxygen and hydrogen, the nitrogen element. Here studies must be concentrated to find in the 
coming years and sources of nitrogen directly on the planet today, which we want to turn into a second blue planet in our solar system soon.

\section{Discussion}

New bases built on Mars where people live are not only necessary but imperative to be built as quickly as possible.

Why is there an extension of the human species in space? Simple, because we will not all be here soon and after we're getting busy, we're gonna consume almost all of the planet's resources and then we'll have enormous social problems.

The man, as I have already said in other works, was not created here only to eat, drink and have fun. Our major humanitarian goal is to become multiple builders on various levels. Over time, we have been able to make the blue planet special beauties built by humans, which even rivals those given by nature. But the big problem is that we will get more and more and resources will diminish. We have succeeded in starting to implement the green energy, especially the hydro, solar and wind, together with the initial nuclear fission energies soon and fusion and thus we will have energy at infinity, here on earth and wherever we go, energy to live, to move, to build and to other major needs.

Unfortunately, not only energy was the only problem with consumables. An essential issue is also the provision of food and drinking water for the entire population of the planet. Here too great steps have been taken and food and water have been multiplied and transported or created everywhere. However, sources of this kind slowly begin to exhaust themselves. It is no longer energy that can even be obtained at infinity, clean, cheap and peaceful, renewable and sustainable. Food and drinking water are two distinct issues that need to be treated with seriousness.

There will be serious problems with housing, jobs, clothing, socialization...

A wise word says it's better to go ahead than to fight. Whenever the population of the planet grew too fast in relation to technology development and this report was deficient and people did not have any real resources to live on Earth, there were plague, cholera and other diseases that were hard to heal in past, or wars, all these incurable diseases at that time, or wars, the ruthlessly ruining the active population of the planet restoring resource-technology balance.

Such an adjustment mechanism is no longer desirable and in addition, it will come sometime when it will not even work, even if the technologies will be more advanced because there will be no room for everyone on our blue planet.

I think everyone has already understood that the expansive objective of humanity is real and not just a simple story.
NASA is today among the main promoters of our expansion, constantly coming up with new discoveries and programs to do so.

Several years ago, we tried to convince the specialists that we needed faster and more efficient ships because space shuttles were just some "simple space carts" with which we waste our time.

Finally, this has been understood and today we are on the right track in this regard. Modern ships have already been built and are constantly being developed, just like energy sources.

Instead of reaching Mars in years and years, we managed to shorten the route to one year, six months, then just three months and soon we will have the ability to move to Mars in just a few days, then in a few hours and at the end in just a few minutes.

The basics of Mars have to be conceived in the most serious way yet, NASA's projects in this sense we hope that they have already begun and if we do not we want to provoke NASA on this path to a serious discussion on this subject and to the approval of some initial Martian bases projects.

Before we reach an exoplanet, we can already turn Mars into a blue, lively planet.

\section{Conclusion}

After the older evidence that there is carbon dioxide on Mars made up of oxygen 2 and carbon now we have evidence that there is even normal water on the marble consisting of hydrogen 2 and oxygen.

In other words, we have Martian oxygen combined with carbon and hydrogen, so we can extract oxygen directly to the site to initially create the source of the breathing necessary for those who will originally live in closed bases built on Mars in the form of huge bells, extremely solid, which will be permanently fed with oxygen for human respiration, but also for other beings, including pets.

Our main objective, however, is to create the atmosphere on Mars, a ground-like, welcoming, friendly atmosphere, so that in the end Mars can live in the same way as on Earth.

It is no longer a dream, but an imperative requirement. It is still difficult to conquer the very distant exoplanes we have just discovered and paratroop and yet we will do so slowly over time and then, as much as possible, it is imperative to begin the terratation of our Mars neighbor, showing clear signs that it was habitable or perhaps once inhabited and which today reveals real water, apart from the carbon dioxide that has been discovered for many years in follow.

Hydrogen being the number one element can now be obtained almost anywhere through various nuclear reactions. If we have oxygen extracted from the layers of $\mathrm{CO}_{2}$ or the water we have found recently, we can create a source of breath and then we can produce water in 
massive quantities, with the obvious purpose of rebuilding the friendly atmosphere of Mars to create a natural water circuit on Mars, even if originally it will be artificially produced using modern technologies.

To create water on Mars, we already have clear possibilities due to the existence of oxygen and the possibility of extraction and hydrogen extraction. For a normal atmosphere and on Mars it is also necessary, besides oxygen and hydrogen, the nitrogen element. Here studies must be concentrated to find in the coming years and sources of nitrogen directly on the planet today, which we want to turn into a second blue planet in our solar system soon.

Before we reach an exoplanet, we can already turn Mars into a blue, lively planet.

\section{Acknowledgement}

We acknowledge and thank $\mathrm{Mr}$ Taher M. AbuLebdeh, Associate Prof at North Carolina A and T State Univesity, United States and Mr Muftah H. El-Naas PhD MCIC FICCE QAFCO Chair Professor in Chemical Process Engineering Gas Processing Center College of Engineering Qatar University and Ms Shweta Agarwala, Senior Research Scientist at Singapore Center for 3D Printing Nanyang Technological University Singapore for their suggestions and comments.

\section{Funding Information}

Research contract: Contract number 36-5-4D/1986 from 24IV1985, beneficiary CNST RO (Romanian National Center for Science and Technology) Improving dynamic mechanisms internal combustion engines. All these matters are copyrighted. Copyrights: 548cgiywDssin, from: 22-04-2010, 08:48:48.

\section{Author's Contributions}

All the authors contributed equally to prepare, develop and carry out this manuscript.

\section{Ethics}

This article is original and contains unpublished material. The corresponding author confirms that all of the other authors have read and approved the manuscript and no ethical issues involved.

\section{References}

Aversa, R., F.I.T. Petrescu, R.V. Petrescu and A. Apicella, 2016a. Biomimetic FEA bone modeling for customized hybrid biological prostheses development. Am. J. Applied Sci., 13: 1060-1067. DOI: 10.3844/ajassp.2016.1060.1067
Aversa, R., D. Parcesepe, R.V. Petrescu, G. Chen and F.I.T. Petrescu et al., 2016b. Glassy amorphous metal injection molded induced morphological defects. Am. J. Applied Sci., 13: 1476-1482. DOI: 10.3844 /ajassp.2016.1476.1482

Aversa, R., R.V. Petrescu, F.I.T. Petrescu and A. Apicella, 2016c. Smart-factory: Optimization and process control of composite centrifuged pipes. Am. J. Applied Sci., 13: 1330-1341.

DOI: 10.3844 /ajassp.2016.1330.1341

Aversa, R., F. Tamburrino, R.V. Petrescu, F.I.T. Petrescu and M. Artur et al., 2016d. Biomechanically inspired shape memory effect machines driven by muscle like acting NiTi alloys. Am. J. Applied Sci., 13: 1264-1271. DOI: 10.3844/ajassp.2016.1264.1271

Aversa, R., E.M. Buzea, R.V. Petrescu, A. Apicella and M. Neacsa et al., 2016e. Present a mechatronic system having able to determine the concentration of carotenoids. Am. J. Eng. Applied Sci., 9: 1106-1111. DOI: 10.3844/ajeassp.2016.1106.1111

Aversa, R., R.V. Petrescu, R. Sorrentino, F.I.T. Petrescu and A. Apicella, 2016f. Hybrid ceramo-polymeric nanocomposite for biomimetic scaffolds design and preparation. Am. J. Eng. Applied Sci., 9: 1096-1105. DOI: 10.3844/ajeassp.2016.1096.1105

Aversa, R., V. Perrotta, R.V. Petrescu, C. Misiano and F.I.T. Petrescu et al., 2016g. From structural colors to super-hydrophobicity and achromatic transparent protective coatings: Ion plating plasma assisted $\mathrm{TiO}_{2}$ and $\mathrm{SiO}_{2}$ Nano-film deposition. Am. J. Eng. Applied Sci., 9: 1037-1045. DOI: 10.3844/ajeassp.2016.1037.1045

Aversa, R., R.V. Petrescu, F.I.T. Petrescu and A. Apicella, 2016h. Biomimetic and evolutionary design driven innovation in sustainable products development. Am. J. Eng. Applied Sci., 9: 1027-1036. DOI: 10.3844/ajeassp.2016.1027.1036

Aversa, R., R.V. Petrescu, A. Apicella and F.I.T. Petrescu, 2016i. Mitochondria are naturally micro robots-a review. Am. J. Eng. Applied Sci., 9: 991-1002. DOI: 10.3844/ajeassp.2016.991.1002

Aversa, R., R.V. Petrescu, A. Apicella and F.I.T. Petrescu, 2016j. We are addicted to vitamins $\mathrm{C}$ and E-A review. Am. J. Eng. Applied Sci., 9: 1003-1018. DOI: 10.3844/ajeassp.2016.1003.1018

Aversa, R., R.V. Petrescu, A. Apicella and F.I.T. Petrescu, 2016k. Physiologic human fluids and swelling behavior of hydrophilic biocompatible hybrid ceramo-polymeric materials. Am. J. Eng. Applied Sci., 9: 962-972.

DOI: 10.3844/ajeassp.2016.962.972

Aversa, R., R.V. Petrescu, A. Apicella and F.I.T. Petrescu, 20161. One can slow down the aging through antioxidants. Am. J. Eng. Applied Sci., 9: 1112-1126. DOI: 10.3844/ajeassp.2016.1112.1126 
Aversa, R., R.V. Petrescu, A. Apicella and F.I.T. Petrescu, 2016m. About homeopathy or «Similia similibus curentur $\gg$. Am. J. Eng. Applied Sci., 9: 1164-1172. DOI: 10.3844/ajeassp.2016.1164.1172

Aversa, R., R.V. Petrescu, A. Apicella and F.I.T. Petrescu, 2016n. The basic elements of life's. Am. J. Eng. Applied Sci., 9: 1189-1197.

DOI: 10.3844/ajeassp.2016.1189.1197

Aversa, R., F.I.T. Petrescu, R.V. Petrescu and A. Apicella, 2016o. Flexible stem trabecular prostheses. Am. J. Eng. Applied Sci., 9: 1213-1221. DOI: 10.3844/ajeassp.2016.1213.1221

Aversa, R., R.V.V. Petrescu, A. Apicella and F.I.T. Petrescu, 2017a. Nano-diamond hybrid materials for structural biomedical application. Am. J. Biochem. Biotechnol., 13: 34-41. DOI: 10.3844/ajbbsp.2017.34.41

Aversa, R., R.V. Petrescu, B. Akash, R.B. Bucinell and J.M. Corchado et al., 2017b. Kinematics and forces to a new model forging manipulator. Am. J. Applied Sci., 14: 60-80. DOI: 10.3844/ajassp.2017.60.80

Aversa, R., R.V. Petrescu, A. Apicella, I.T.F. Petrescu and J.K. Calautit et al., 2017c. Something about the V engines design. Am. J. Applied Sci., 14: 34-52. DOI: 10.3844/ajassp.2017.34.52

Aversa, R., D. Parcesepe, R.V.V. Petrescu, F. Berto and G. Chen et al., 2017d. Process ability of bulk metallic glasses. Am. J. Applied Sci., 14: 294-301. DOI: 10.3844/ajassp.2017.294.301

Aversa, R., R.V.V. Petrescu, B. Akash, R.B. Bucinell and J.M. Corchado et al., 2017e. Something about the balancing of thermal motors. Am. J. Eng. Applied Sci., 10: 200-217. DOI: 10.3844/ajeassp.2017.200.217

Aversa, R., R.V. Petrescu, A. Apicella and F.I.T. Petrescu, 2017f. Modern transportation and photovoltaic energy for urban ecotourism. Transylvanian Rev. Admin. Sci., 13: 5-20. DOI: 10.24193/tras.SI2017.1

Berto, F., R.V.V. Petrescu and F.I.T. Petrescu, 2016a. A review of recent results on $3 \mathrm{D}$ effects. Am. J. Eng. Applied Sci., 9: 1247-1260. DOI: 10.3844 /ajeassp.2016.1247.1260

Berto, F., R.V.V. Petrescu and F.I.T. Petrescu, 2016b. Three-dimensional in bonded joints: A short review. Am. J. Eng. Applied Sci., 9: 1261-1268. DOI: 10.3844/ajeassp.2016.1261.1268

Berto, F., A. Gagani, R.V.V. Petrescu and F.I.T. Petrescu, 2016c. Key-hole notches in isostatic graphite: A review of some recent data. Am. J. Eng. Applied Sci., 9: 1292-1300. DOI: 10.3844 /ajeassp.2016.1292.1300

Berto, F., A. Gagani, R. Aversa, R.V.V. Petrescu and A. Apicella et al., 2016d. Multiaxial fatigue strength to notched specimens made of 40CrMoV13.9. Am. J. Eng. Applied Sci., 9: 1269-1291.

DOI: 10.3844/ajeassp.2016.1269.1291
Mirsayar, M.M., V.A. Joneidi, R.V.V. Petrescu, F.I.T. Petrescu and F. Berto, 2017. Extended MTSN criterion for fracture analysis of soda lime glass. Eng. Fracture Mechan., 178: 50-59.

DOI: $10.1016 /$ j.engfracmech.2017.04.018

Petrescu, F.I.T., 2009. New aircraft. Proceedings of the 3rd International Conference on Computational Mechanics, Oct. 29-30, Brasov, Romania.

Petrescu, F.I.T., 2012a. Cold Nuclear Fusion. 1st Edn., Create Space, USA, ISBN-10: 1478234261, pp: 80.

Petrescu, F.I.T., 2012b. Particle annihilation - a source of renewable energy? Infinite Energy Magazine, LuLu Publishers, USA.

Petrescu, F.I.T., 2016 Valorificarea Traditiei Ingineresti Romanesti-I. 1st Edn., CreateSpace Independent Publishing Platform, ISBN-10: 1536889946, pp: 152.

Petrescu, F.I.T. and J.K. Calautit, 2016a. About nano fusion and dynamic fusion. Am. J. Applied Sci., 13: 261-266. DOI: 10.3844/ajassp.2016.261.266

Petrescu, F.I. and J.K. Calautit, 2016b. About the light dimensions. Am. J. Applied Sci., 13: 321-325. DOI: 10.3844 /ajassp.2016.321.325

Petrescu, F.I. and R.V. Petrescu, 2011 a. Memories about Flight. 1st Edn., CreateSpace, pp: 652.

Petrescu, F.I. and R.V. Petrescu, 2011b. Mechanical Systems, Serial and Parallel. 1st Edn., lulu.com Publisher, London, UK. ISBN-10: 1446600394, pp: 124.

Petrescu, R.V. and F.I.T. Petrescu, 2012a. Northrop. 1st Edn., Books on Demand, ISBN-10: 3848209322 , pp: 142.

Petrescu, F.I. and R.V. Petrescu, 2012b. New Aircraft II. 1st Edn., Books on Demand, pp: 138.

Petrescu, F.I. and R.V. Petrescu, 2012c. MecatronicaSisteme Seriale Si Paralele. 1st Edn., Create Space Publisher, USA, ISBN-13: 978-1-4750-6613-5, pp: 128.

Petrescu, F.I. and R.V. Petrescu, 2012d. Kinematics of the planar quadrilateral mechanism. ENGEVISTA, 14: 345-348.

Petrescu, R.V. and F.I. Petrescu, 2013a. Lockheed Martin. 1st Edn., CreateSpace, pp: 114.

Petrescu, R.V. and F.I. Petrescu, 2013b. Northrop. 1st Edn., CreateSpace, pp: 96.

Petrescu, R.V. and F.I. Petrescu, 2013c. The Aviation History or New Aircraft I Color. 1st Edn., CreateSpace, pp: 292.

Petrescu, F.I. and R.V. Petrescu, 2013d. Cinematics of the 3R dyad. ENGEVISTA, 15: 118-124.

Petrescu, F.I. and R.V. Petrescu, 2016a. Parallel moving mechanical systems kinematics. ENGEVISTA, 18:455-491.

Petrescu, F.I. and R.V. Petrescu, 2016b. Direct and inverse kinematics to the anthropomorphic robots. ENGEVISTA, 18: 109-124. 
Petrescu, F.I. and R.V. Petrescu, 2016c. Dynamic cinematic to a structure 2R. Revista Geintec-Gestao Inovacao E Tecnol., 6: 3143-3154.

Petrescu, R.V.V., R. Aversa, A. Apicella, F. Berto and S. Li et al., 2016a. Ecosphere protection through green energy. Am. J. Applied Sci., 13: 1027-1032.

DOI: 10.3844 /ajassp.2016.1027.1032

Petrescu, F.I.T., A. Apicella, R.V.V. Petrescu, S.P. Kozaitis and R.B. Bucinell et al., $2016 \mathrm{~b}$. Environmental protection through nuclear energy. Am. J. Applied Sci., 13:941-946.

DOI: 10.3844/ajassp.2016.941.946

Petrescu, R.V., R. Aversa, A. Apicella and F.I. Petrescu, 2016c. Future medicine services robotics. Am. J. Eng. Applied Sci., 9: 1062-1087. DOI: 10.3844/ajeassp.2016.1062.1087

Petrescu, R.V., R. Aversa, B. Akash, F. Berto and A. Apicella et al., 2017a. Forces of a 3R Robot. J. Mechatron. Robot., 1: 1-14. DOI: $10.3844 /$ jmrsp.2017.1.14

Petrescu, R.V., R. Aversa, B. Akash, F. Berto and A. Apicella et al., 2017b. Direct geometry and cinematic to the MP-3R systems. J. Mechatron. Robot., 1: 15-23. DOI: 10.3844/jmrsp.2017.15.23

Petrescu, R.V., R. Aversa, B. Akash, F. Berto and A. Apicella et al., 2017c. Dynamic elements at MP3R. J. Mechatron. Robot., 1: 24-37. DOI: $10.3844 /$ jmrsp.2017.24.37

Petrescu, R.V., R. Aversa, B. Akash, F. Berto, A. Apicella and F.I.T. Petrescu, 2017d. Geometry and direct kinematics to MP3R with $4 \times 4$ operators. J. Mechatron. Robot., 1: 38-46. DOI: $10.3844 /$ jmrsp.2017.38.46

Petrescu, R.V., R. Aversa, A. Apicella, M.M. Mirsayar and S. Kozaitis et al., 2017e. Current stage in the field of mechanisms with gears and rods. J. Mechatron. Robot., 1: 47-57. DOI: $10.3844 / \mathrm{jmrsp} .2017 .47 .57$

Petrescu, R.V., R. Aversa, A. Apicella, M.M. Mirsayar and S. Kozaitis et al., 2017f. Geometry and inverse kinematic at the MP3R mobile systems. J. Mechatron. Robot., 1: 58-65. DOI: $10.3844 /$ jmrsp.2017.58.65
Petrescu, R.V., R. Aversa, A. Apicella, M.M. Mirsayar and S. Kozaitis et al., 2017g. Synthesis of optimal trajectories with functions control at the level of the kinematic drive couplings. J. Mechatron. Robot., 1: 66-74. DOI: 10.3844 /jmrsp.2017.66.74

Petrescu, R.V., R. Aversa, A. Apicella, M.M. Mirsayar and S. Kozaitis et al., 2017h. The inverse kinematics of the plane system 2-3 in a mechatronic MP2R system by a trigonometric method. J. Mechatron. Robot., 1: 75-87. DOI: 10.3844/jmrsp.2017.75.87

Petrescu, R.V., R. Aversa, A. Apicella, M.M. Mirsayar and S. Kozaitis et al., 2017i. Serial, anthropomorphic, spatial, mechatronic systems can be studied more simply in a plan. J. Mechatron. Robot., 1: 88-97. DOI: 10.3844/jmrsp.2017.88.97

Petrescu, R.V., R. Aversa, A. Apicella, M.M. Mirsayar and S. Kozaitis et al., 2017j. Analysis and synthesis of mechanisms with bars and gears used in robots and manipulators. J. Mechatron. Robot., 1: 98-108. DOI: $10.3844 /$ jmrsp.2017.98.108

Petrescu, R.V., R. Aversa, A. Apicella, M.M. Mirsayar and S. Kozaitis et al., 2017k. Speeds and accelerations in direct kinematics to the MP3R systems. J. Mechatron. Robot., 1: 109-117. DOI: $10.3844 /$ jmrsp.2017.109.117

Petrescu, R.V., R. Aversa, A. Apicella, M.M. Mirsayar and S. Kozaitis et al., 20171. Geometry and determining the positions of a plan transporter manipulator. J. Mechatron. Robot., 1: 118-126. DOI: 10.3844 /jmrsp.2017.118.126

Webster, G., J. LaVista, L. Cantillo and D. Brown, 2018. Steep slopes on mars reveal structure of buried ice. Jet Propulsion Laboratory, Pasadena, California Institute of Technology.

\section{Source of Figures}

Fig. 1:

https://www.jpl.nasa.gov/spaceimages/details.php?id=PI A22077

Fig. 2:

https://www.jpl.nasa.gov/spaceimages/details.php?id=PI A22078

Fig. 3:

https://www.nasa.gov/image-feature/jpl/a-world-ofsnowy-dunes 